\title{
PERANCANGAN WEBSITE DINAS PENDIDIKAN PEMUDA DAN OLAH RAGA (STUDI KASUS DINAS PENDIDIKAN PEMUDA DAN OLAH RAGA KABUPATEN KEBUMEN)
}

\author{
Ari Waluyo, El Vionna Laellyn Nurul Fatich \\ Program Studi Manajemen Informatika, Politeknik Piksi Ganesha Bandung \\ ari@politeknik-kebumen.ac.id, vionna3008@gmail.com
}

\begin{abstract}
The research have goal to design the Dinas Pendidikan, Pemuda dan Olah Raga website using PHP programming language and MySQL database at Dinas Pendidikan, Pemuda dan Olah Raga in Kebumen. Reseach method have used in this research is qualitative with descriptive method. Data collection technique is observation, interview, and literature review which have connection with main problem. The system development method which used is SDLC (System Development Life Circle). From the result of research have problems such as the menu provided too much and the information presented is not grouped properly. It made the user still feel difficulty in finding the needed information. There are recommendations which give to solving the problem are: 1) grouping the menus to easier finding informations, 2) re-design website that can show the information with categories, and 3) make the user-friendly website design.
\end{abstract}

Keywords : Systems Design, Website, Dinas Pendidikan, Pemuda dan Olah Raga Kabupaten Kebumen.

\begin{abstract}
Abstrak
Penelitian ini bertujuan untuk merancang website Dinas Pendidikan, Pemuda dan Olah Raga dengan menggunakan bahasa pemrograman PHP dan database MySQL di Dinas Pendidikan, Pemuda, dan Olah Raga Kabupaten Kebumen. Metode penelitian yang digunakan dalam penelitian ini adalah metode kualitatif dengan pendekatan deskriptif. Teknik pengumpulan data yang digunakan adalah dengan cara observasi, wawancara serta kajian pustaka yang memiliki hubungan erat dengan pokok permasalahan. Metode pengembangan sistem yang digunakan dalam penelitian ini adalah metode pengembangan sistem SDLC (System Development Life Circle). Dari hasil penelitian yang dilakukan ditemukan permasalahan seperti menu yang tersedia terlalu banyak dan informasi yang disajikan belum terkelompokkan dengan baik. Hal ini membuat pengguna masih merasa kesulitan dalam mencari informasi yang dibutuhkan. Adapun saran yang diberikan untuk mengatasi masalah tersebut adalah: 1) mengelompokkan kembali menu-menu yang ada untuk lebih memudahkan pencarian informasi, 2) merancang ulang website yang dapat menampilkan informasi per kategori, dan 3) membuat rancangan website yang lebih user-friendly.
\end{abstract}

Kata Kunci : Perancangan Sistem, Website, Dinas Pendidikan Pemuda dan Olah Raga Kabupaten Kebumen 


\section{PENDAHULUAN}

Perkembangan teknologi informasi yang cepat di Indonesia telah membawa perubahan baru dalam perilaku masyarakat dalam segala aktivitas keseharian baik aktivitas pribadi maupun aktivitas sebuah lembaga/instansi/perusahaan. Kecenderungan masyarakat Indonesia saat ini sangat bergantung pada sesuatu yang digital, paradigma ini muncul sebagai akibat kompleksitas segala aspek kehidupan yang menuntut segala proses terjadi secara cepat, tepat, akurat, efektif dan efisien. Salah satu pemanfaatan teknologi informasi dan komunikasi pada lingkungan instansi pemerintahan adalah dibangunnya sebuah website. Pengguna dapat memperoleh informasi secara online tanpa harus datang secara fisik ke instansi terkait. Berdasarkan manfaat yang diperoleh dengan keberadaan website, maka selayaknya sebuah instansi membangun website resmi dan kemudian mengembangkannya menjadi lebih baik.

Dinas Pendidikan, Pemuda dan Olah Raga Kabupaten Kebumen merupakan salah satu instansi pemerintah yang telah membangun website resmi berbasis PHP dibawah pengawasan pemerintah Kabupaten Kebumen dengan alamat "disdikpora.kebumenkab.go.id". Namun dalam penerapannya, website Dinas Pendidikan, Pemuda dan Olah Raga Kabupaten Kebumen dirasa masih menemukan beberapa kelemahan. Beberapa kelemahan dalam website Dinas Pendidikan, Pemuda dan Olah Raga Kabupaten Kebumen adalah menu yang tersedia kurang efektif dan informasi yang disajikan belum terkelompokkan dengan baik, sehingga hal ini membuat pengguna masih merasa kesulitan dalam mencari informasi yang dibutuhkan.

Berdasarkan latar belakang diatas maka dapat ditarik pokok permasalahan yaitu "Bagaimana merancang website Dinas Pendidikan, Pemuda dan Olah Raga menggunakan PHP dan MySQL di Dinas Pendidikan, Pemuda dan Olah Raga Pemerintah Kabupaten Kebumen?".

\section{METODOLOGI PENELITIAN}

\subsection{Pegertian Sistem}

Menurut Pamudji dalam [1], sistem adalah suatu himpunan atau perpaduan hal-hal atau bagian-bagian yang membentuk suatu kebulatan/keseluruhan yang kompleks atau utuh. Suatu sistem akan didefinisikan sebagai suatu gugus komponen-komponen yang dirancang untuk menyelesaikan suatu tujuan tertentu sesuai dengan rencana. Sistem adalah suatu jaringan kerja dari prosedur-prosedur yang saling berhubungan, berkumpul bersama-sama untuk melakukan suatu kegiatan atau untuk menyelesaikan suatu sasaran yang tertentu [2].

\subsection{Pengertian Informasi}

Informasi diartikan sebagai data yang diolah menjadi bentuk lebih berguna dan lebih berarti bagi yang menerimanya [2]. 


\subsection{Pengertian Sistem Informasi}

Sistem informasi merupakan suatu sistem yang dibuat oleh manusia yang terdiri dari komponen-komponen dalam organisasi untuk mencapai suatu tujuan yaitu menyajikan informasi [3].

Menurut [4] sistem Informasi Manajemen (SIM) dapat didefinisikan sebagai suatu alat untuk menyajikan informasi dengan cara sedemikian rupa sehingga bermanfaat bagi penerimanya [5]. Tujuannya adalah untuk menyajikan informasi guna pengambilan keputusan pada perencanaan, pemrakarsaan, pengorganisasian, pengendalia kegiatan operasi subsistem suatu perusahaan, dan menyajikan sinergi organisasi pada proses [6].

\subsection{Perancangan Sistem}

Perancangan sistem adalah proses menyusun atau mengembangkan sistem informasi yang baru. Dalam tahap ini harus dapat dipastikan bahwa semua persyaratan untuk menghasilkan sistem informasi dapat dipenuhi. Hasil sistem yang dirancang harus sesuai dengan kebutuhan pemakai untuk mendapatkan informasi.

\subsection{SDLC (System Development Life Cycle)}

Beberapa ahli membagi proses-proses pengembangan sistem ke dalam sejumlah urutan yang berbeda-beda. Tapi semuanya akan mengacu pada proses-proses standar berikut [4] :

1) Analisis

2) Desain

3) Implementasi

4) Pemeliharaan

Pada perkembangannya, proses-proses standar tadi dituangkan dalam satu metode yang dikenal dengan nama System Development Life Cycle (SDLC) yang merupakan metodologi umum dalam pengembangan sistem yang menandai kemajuan usaha analisis dan desain. SDLC meliputi fase-fase sebagai berikut [4] :

1) Identifikasi dan seleksi proyek

2) Inisiasi dan perencanaan proyek

3) Analisis

4) Desain

a) Desain logikal

b) Desain fisikal

5) Implementasi

6) Pemeliharaan

\subsection{Pengertian UML}

Menurut [7] UML (Unified Modelling Language) adalah sistem notasi yang sudah dibakukan di dunia pengembangan sistem, hasil kerja bersama Grady Booch, James Rumbaugh dan Ivar Jacobson. UML yang terdiri dari 
serangkaian diagram yang memungkinkan bagi sistem analis untuk membuat cetak biru sistem yang komprehensif kepada klien, programmer dan tiap orang yang terlibat dalam proses pengembangan sistem tersebut. Sangat penting untuk bisa mengeluarkan semua diagram tersebut, karena setiap diagram bisa mewakili shakeholder yang berbeda di sistem tersebut. Dengan UML akan bisa menceritakan apa yang seharusnya dilakukan oleh sebuah sistem bukan bagaimana yang seharusnya dilakukan oleh sebuah sistem.

\section{HASIL DAN PEMBAHASAN}

3.1. Rancangan Fungsional

\subsubsection{Use Case Diagram}

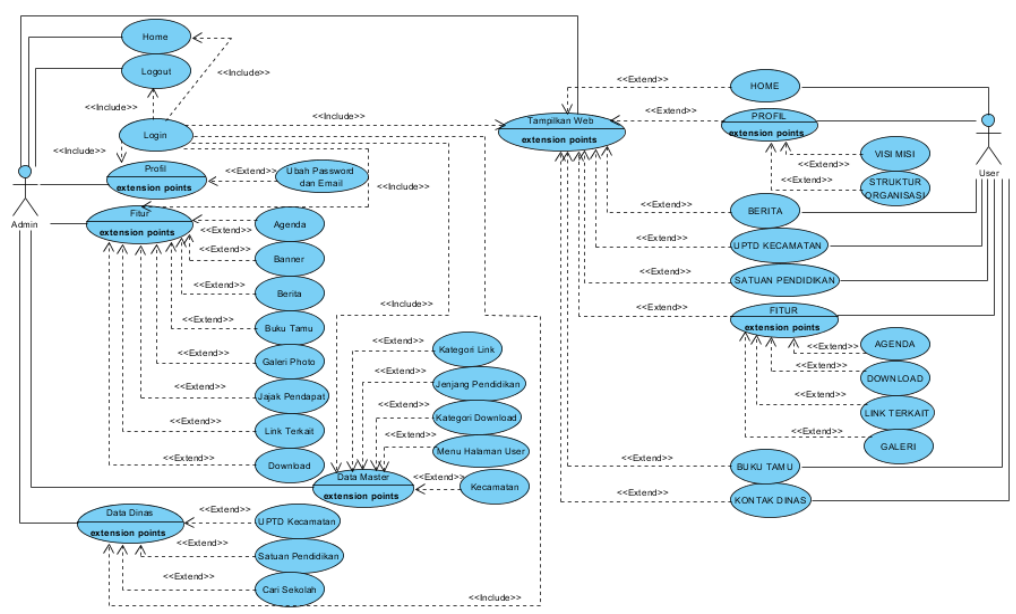

Gambar 1. Use case diagram

\subsubsection{Class Diagram}

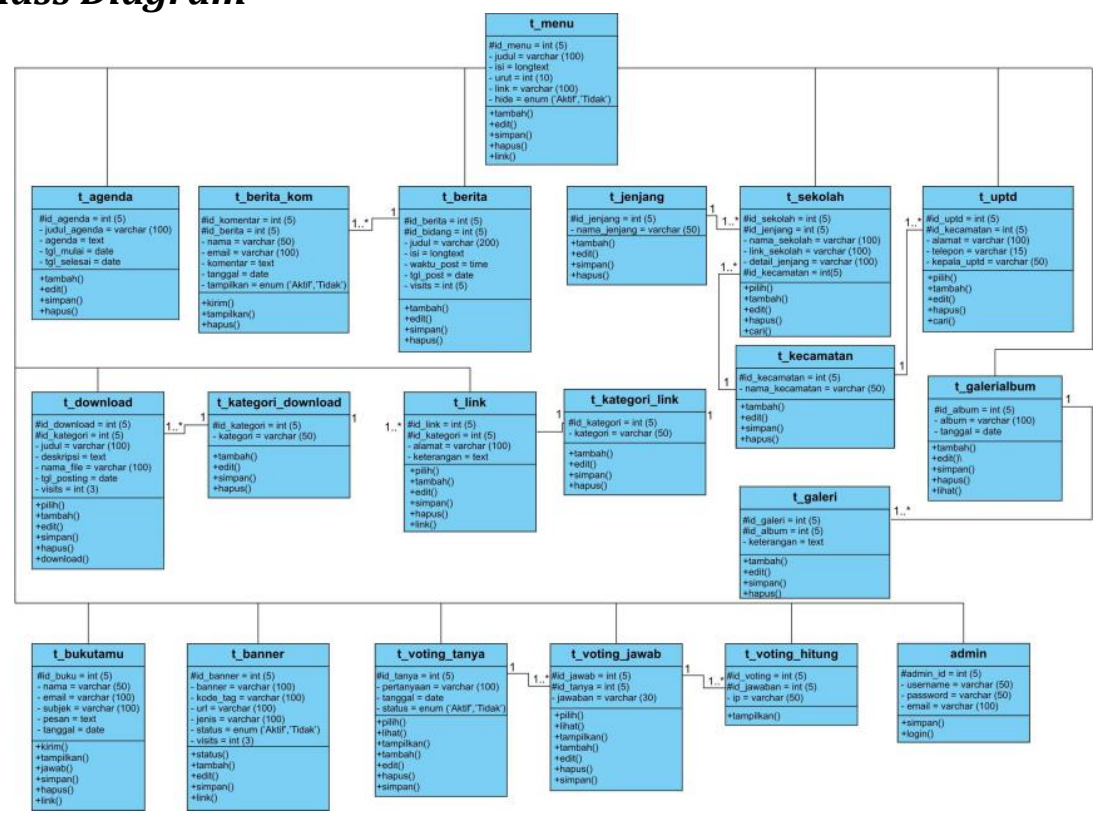

Gambar 2. Class diagram 


\subsubsection{Activity Diagram}

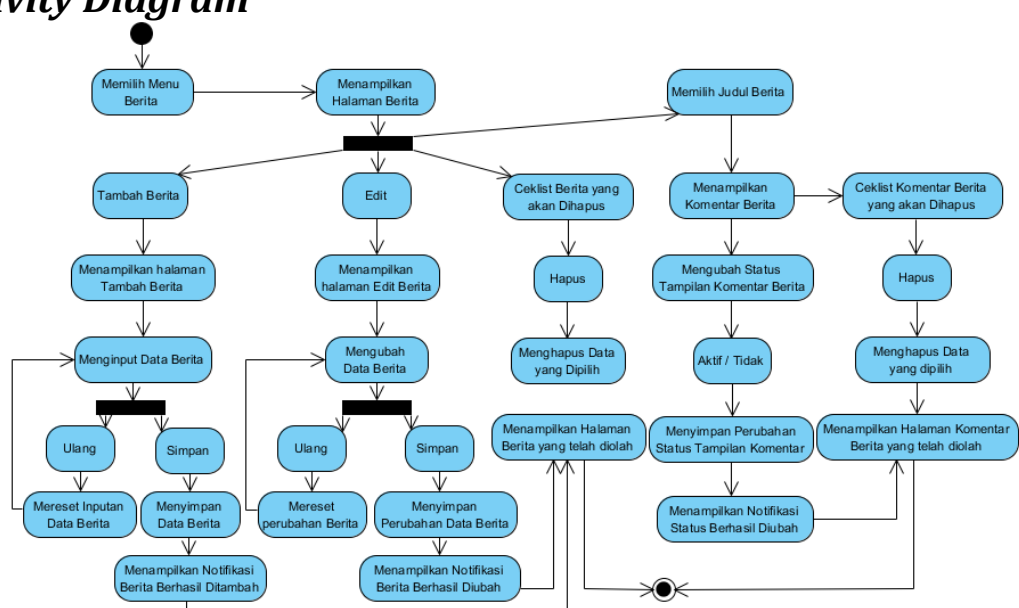

\section{Gambar 3. Activity Diagram Berita Admin}

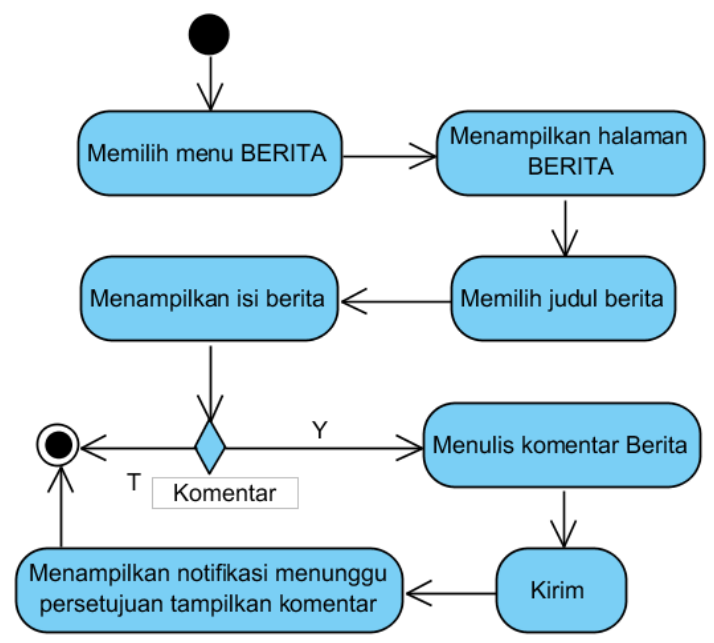

Gambar 4. Activity Diagram Berita User

\subsubsection{Sequence Diagram}

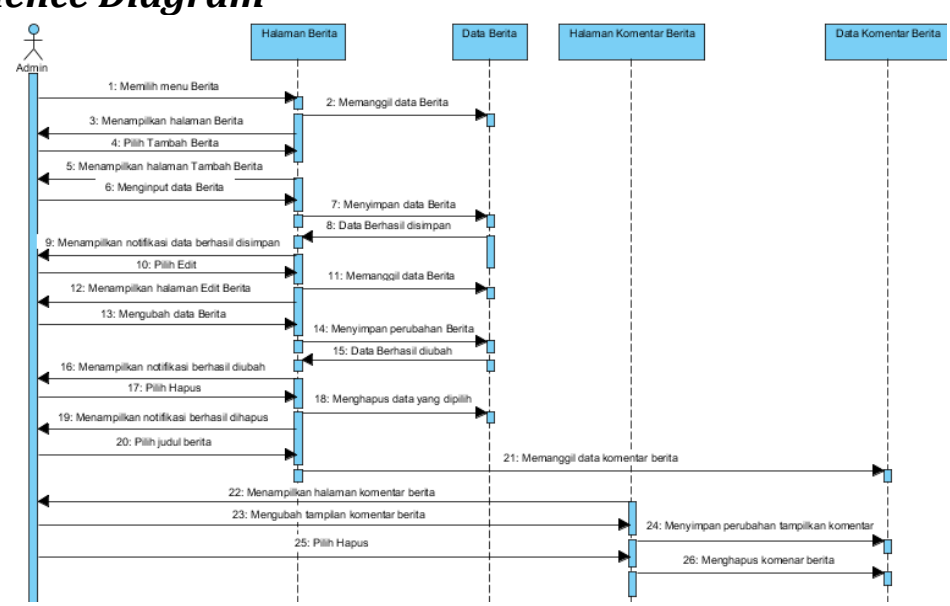

Gambar 5. Sequence Diagram Berita Admin 


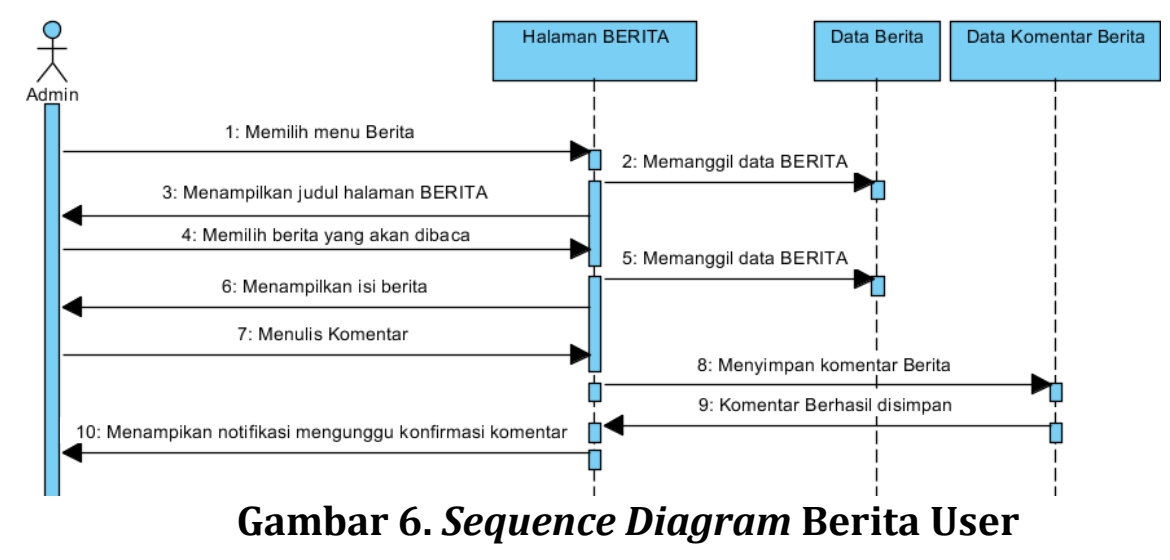

\subsubsection{State Chart Diagram}

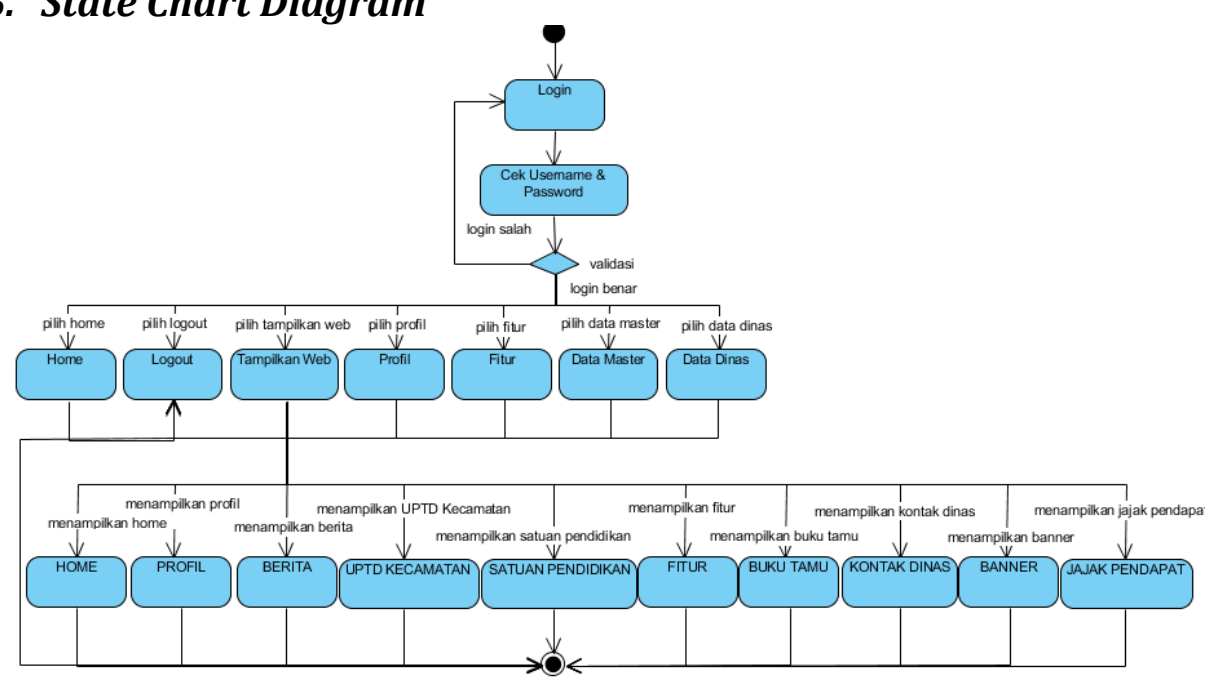

Gambar 7. State Chart Diagram

\subsubsection{Deployment Diagram}

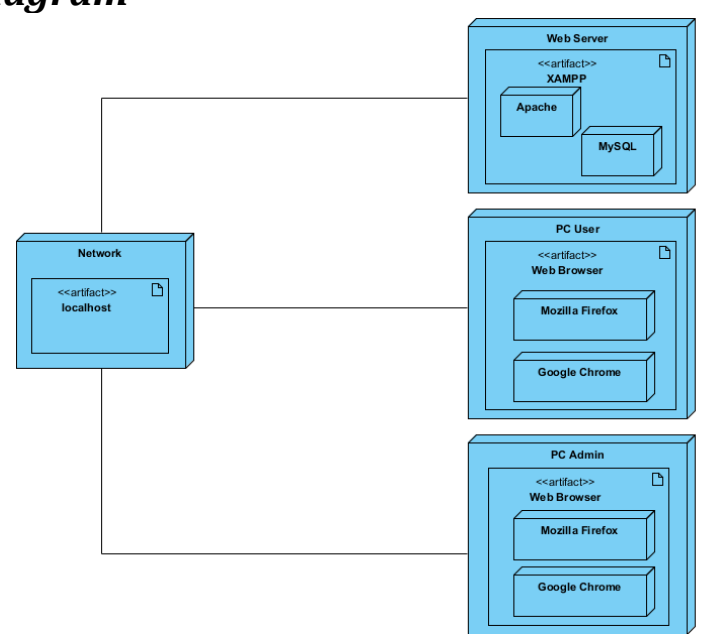

Gambar 8. Deployment Diagram 


\subsubsection{Component Diagram}

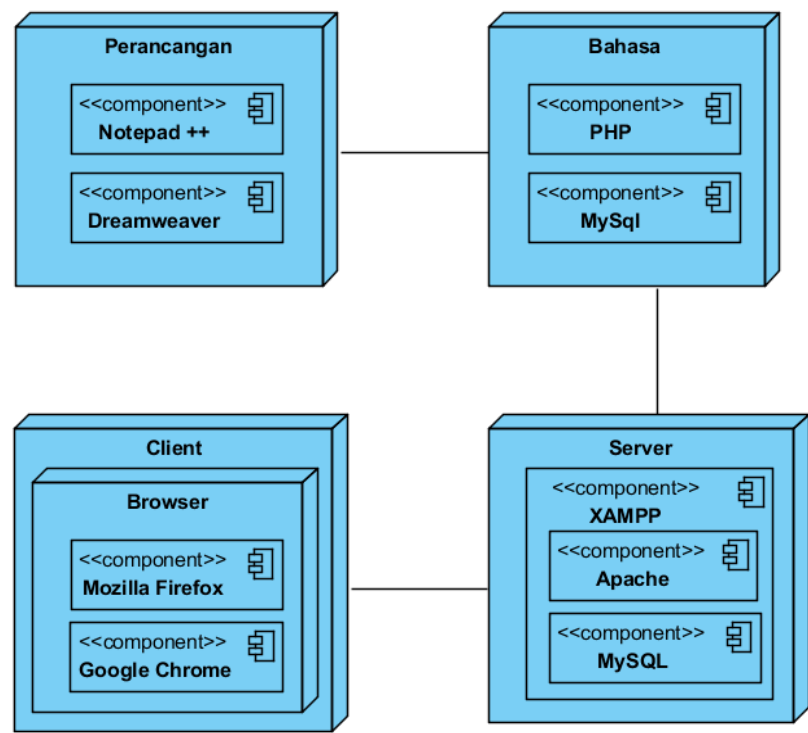

Gambar 9. Component Diagram

\subsection{Rancangan Interface}

1) Login

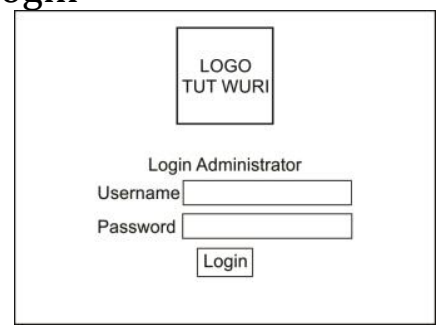

Gambar 10. Rancangan Login

3) Daftar Berita

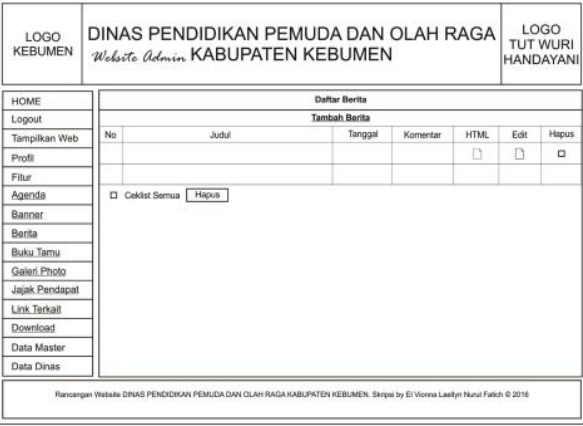

Gambar 12. Rancangan Daftar Berita
2) HOME

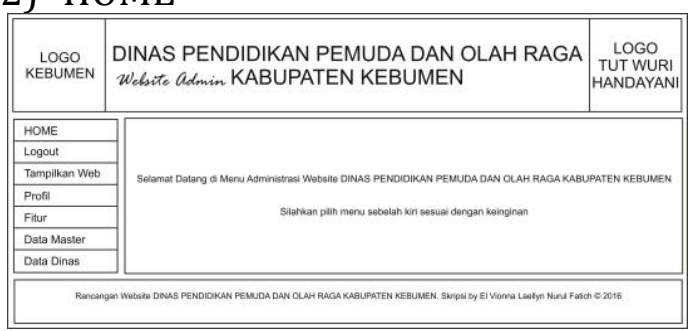

Gambar 11. Rancangan HOME

4) Komentar Berita

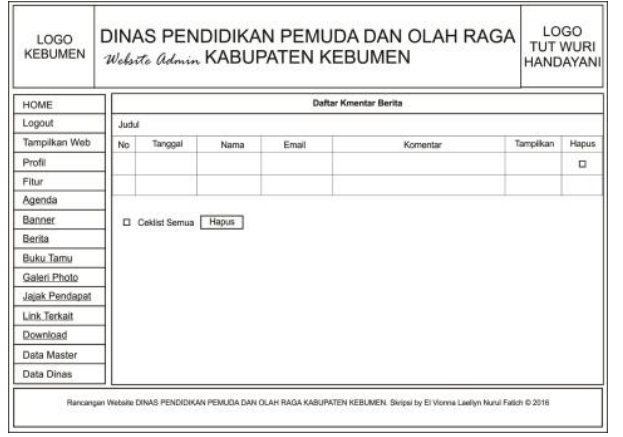

Gambar 13. Halaman Komentar Berita 
5) Tambah dan Edit Berita

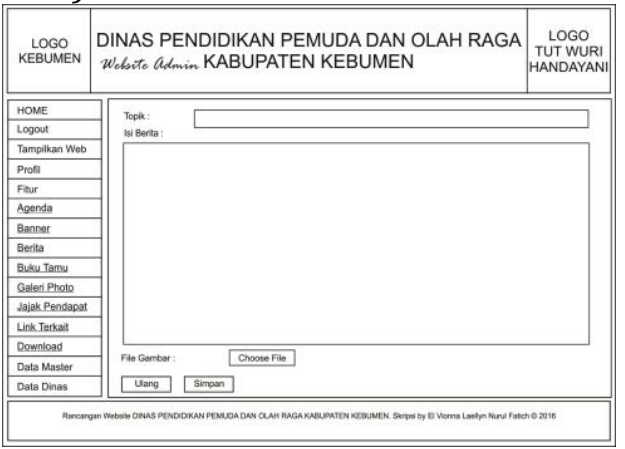

Gambar 14. Halaman Tambah dan Edit Berita
6) Rancangan User

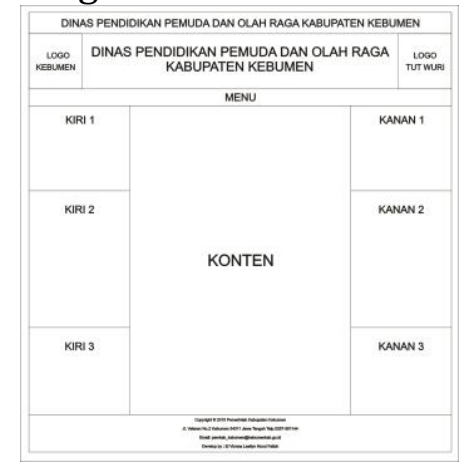

Gambar 15. Rancangan Halaman

User

\subsection{Implementasi}

Implementasi interface merupakan penerapan perancangan format tampilan yang telah dibuat sebelumnya dalam perancangan pengembangan sistem. Adapun implementasi interface dari website Dinas Pendidikan, Pemuda dan Olah Raga Kabupaten Kebumen adalah sebagai berikut :

a. Halaman Admin

1) Login

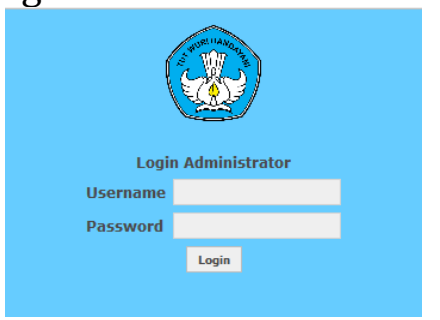

Gambar 16. Halaman Login

3) Daftar Berita

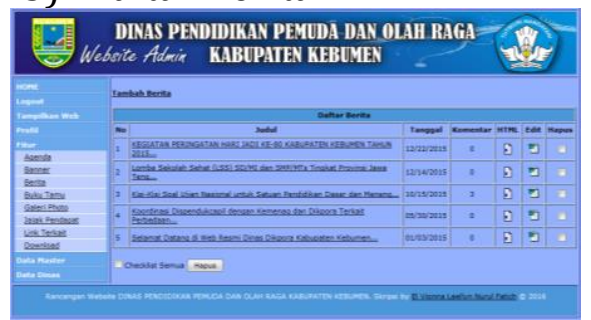

Gambar 18. Halaman Daftar

Berita
2) HOME

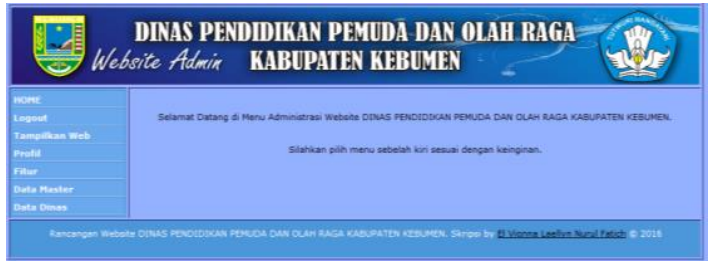

Gambar 17. Halaman HOME

4) Komentar Berita

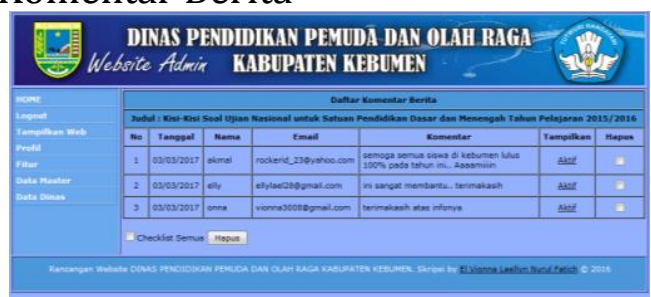

Gambar 19. Halaman Komentar Berita 
5) Tambah atau Edit Berita

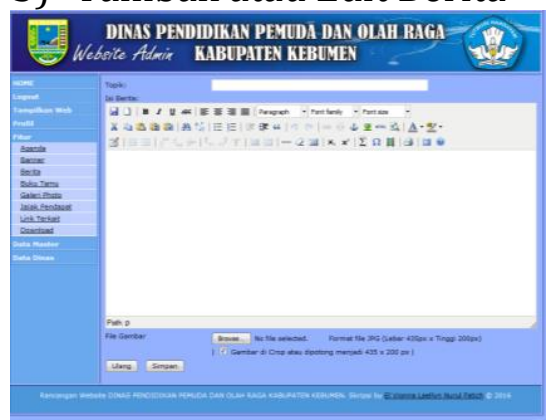

Gambar 20. Halaman Tambah atau Edit Berita

b. Halaman User

1) Home

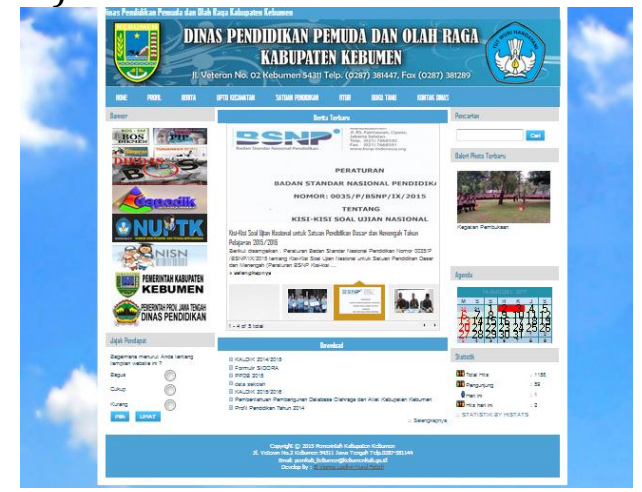

\section{Gambar 21. Halaman Home}

3) Berita

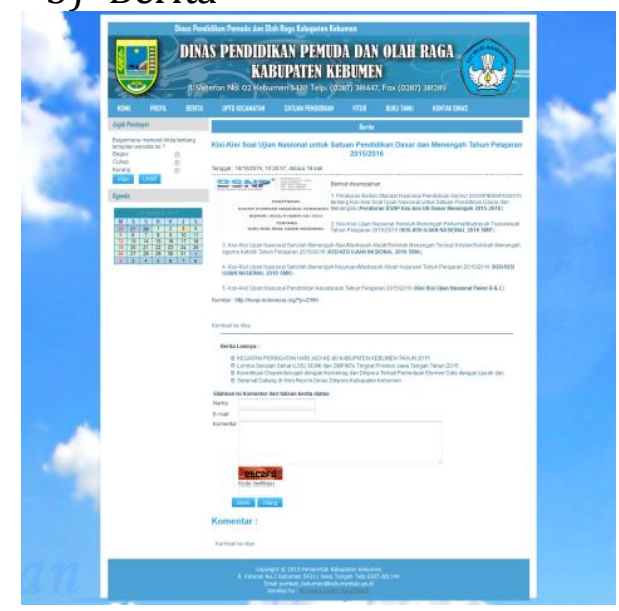

Gambar 23. Halaman Berita
2) Profil

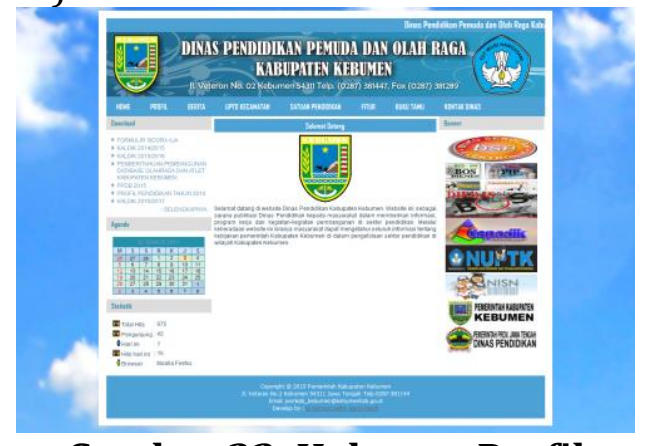

Gambar 22. Halaman Profil

4) UPTD Kecamatan

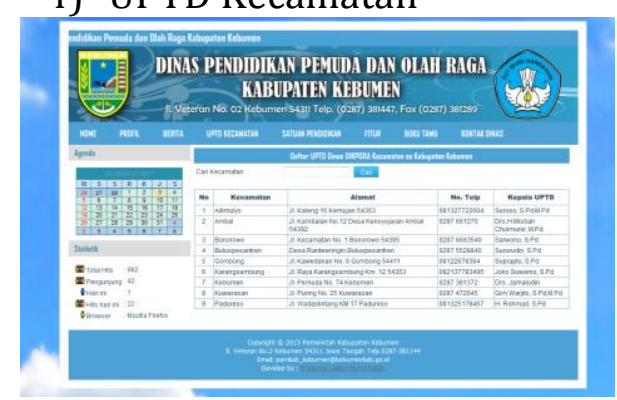

Gambar 24. Halaman UPTD Kecamatan 
5) Satuan Pendidikan

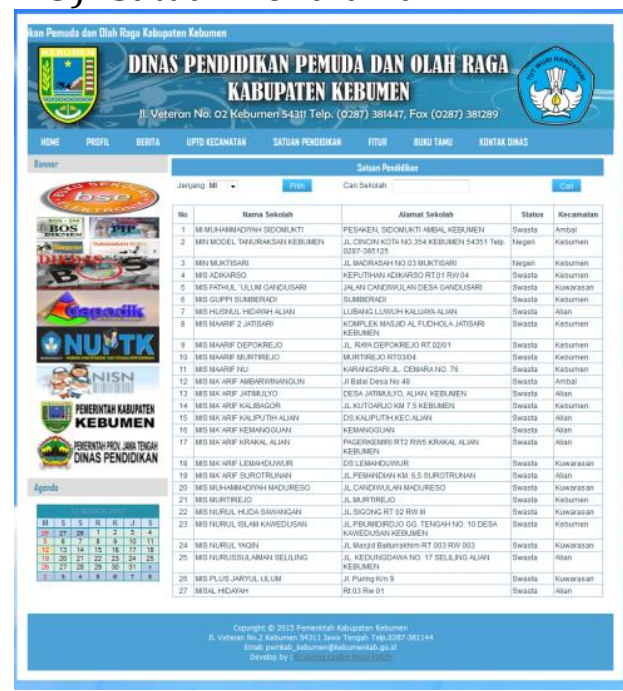

Gambar 25. Halaman Satuan Pendidikan

\section{7) Buku Tamu}

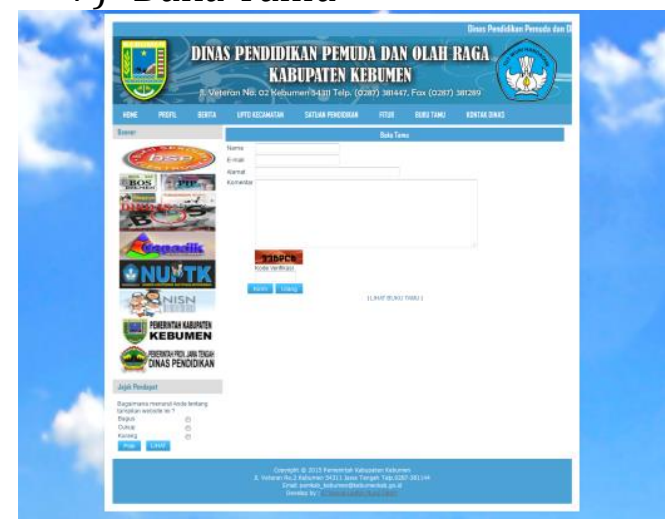

Gambar 27. Halaman Buku Tamu
6) Galeri

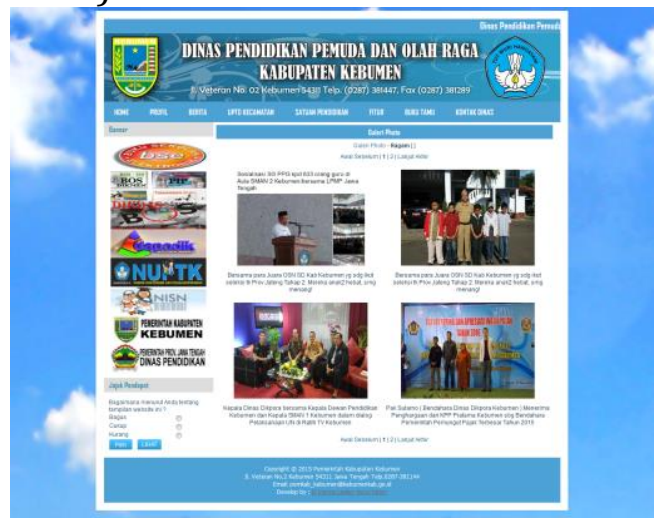

Gambar 26. Halaman Galeri

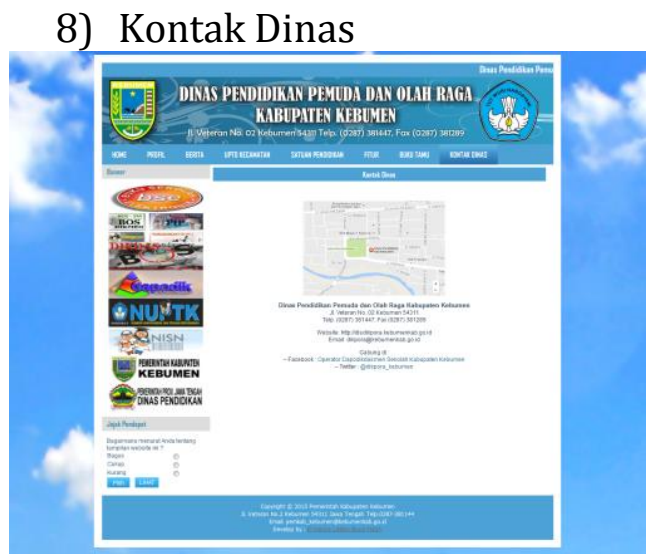

Gambar 28. Halaman Kontak Dinas

\section{SIMPULAN}

Berdasarkan penelitian yang telah dilakukan maka didapatkan beberapa kesimpulan sebagai berikut :

a. Website Dinas Pendidikan, Pemuda dan Olah Raga Kabupaten Kebumen yang ada saat ini masih memiliki beberapa kelemahan, seperti menu yang tersedia dalam website masih terlalu banyak serta informasi yang ada masih bersifat umum dan belum dikelompokkan dalam kategori tertentu. Selain itu, menu dalam website yang ada saat ini dirasa belum tertata dengan baik sehingga masih ada user yang merasa kesulitan dalam mencari informasi. Interaksi dalam website Dinas Pendidikan, 
Pemuda dan Olah Raga Kabupaten Kebumen saat ini hanya sebatas interaksi antara user dengan admin dalam Buku Tamu, belum terdapat interaksi antar user. Hal ini juga menjadi kelemahan dalam website Dinas Pendidikan, Pemuda dan Olah Raga Kabupaten Kebumen.

b. Dalam perancangan website Dinas Pendidikan, Pemuda dan Olah Raga Kabupaten Kebumen menggunakan metode SDLC (System Development Life Cycle), penulis melakukan beberapa tahapan, yakni perencanaan, analisis, desain dan implementasi sistem. Perencanaan dilakukan oleh penulis dengan mewawancarai beberapa narasumber terkait. Kemudian penulis melakukan analisis kebutuhan perancangan website. Selanjutnya penulis melakukan desain logis menggunakan UML (Unified Modelling Language) dan desain fisik menggunakan bahasa pemrograman PHP dan database MySQL. Untuk memastikan sistem berjalan sesuai dengan yang diharapkan, maka penulis melakukan pengujian menggunakan metode Black Box testing. Black box testing ini merupakan metode uji coba yang memfokuskan pada keperluan perangkat lunak.

c. Beberapa keunggulan website hasil rancangan ialah tampilan atau interface yang lebih menarik, pengelompokkan informasi yang lebih sederhana, terdapat interaksi antar user maupun user dengan admin, dan terdapat menu agenda sebagai fitur tambahan dari hasil perancangan website Dinas Pendidikan, Pemuda dan Olah Raga Kabupaten Kebumen.

\section{DATAR PUSTAKA}

[1] Jatnika, Hendra. 2013. Sistem Informasi Manajemen Berbasis Komputer. Yogyakarta : Andi Offset.

[2] Jogiyanto, H.M. 2005. Analisis dan Desain Sistem Informasi. Yogyakarta : Andi Offset.

[3] Wahyono, Teguh. 2004. Sistem Informasi (Konsep Dasar; Analisis Desain dan Implementasi). Yogyakarta : Graha Ilmu.

[4] Al Fatta, Hanif. 2007. Analisis dan Perancangan Sistem Informasi untuk Keunggulan Bersaing Perusahaan dan Organisasi Modern. Yogyakarta : Andi Offset.

[5] Al-Jufri, Hamid. 2011. Sistem Infromasi Manajemen Pendidikan. Jakarta: PT. Smart Grafika.

[6] Darmawan, Deni. 2013. Sistem Informasi Manajemen. Bandung: PT. Remaja Rosdakarya Offset.

[7] Munawar. 2005. Permodelan Visual dengan UML. Jakarta : Graha Ilmu. 